\title{
STUDY OF THE LEVEL OF 25-HYDROXYVITAMIN D IN PATIENTS WITH SEBORRHEIC DERMATITIS
}

\author{
Jenya Dimitrova \\ Department of Dermatology and Venerology, Medical University of Varna
}

\begin{abstract}
PURPOSE: Seborrheic dermatitis is papulo-squamous disorder affecting 3-5\% of the population. Its pathogenesis is not elucidated yet. The purpose of our study was to find out the serum level of 25-hydroxyvitamin D (25-(OH) vit. D) in patients with clinicaly manifested seborrheic dermatitis.

MATERIAL AND METHODS: Twenty-two patients, 11 females and 11males, were examined for serum 25$(\mathrm{OH})$ vit. $\mathrm{D}$. One patient was at remission stage. The values were measured by means of electrochemiluminescence immunoassay analyzer. The study was carried out between November and August.

RESULTS: During the whole period of the study none of the patients showed optimal level of serum 25-(OH) vit $\mathrm{D}$. Three patients presented with suboptimal values of $25-(\mathrm{OH})$ vit. $\mathrm{D}(13,6 \%$ of the cases). The rest 19 patients $(86,3 \%)$ showed insufficiency of $25-(\mathrm{OH})$ vit. D with values under $30 \mathrm{ng} / \mathrm{mL}$ and 13 of them $(68,4 \%)$ were with pronounced deficiency - serum $25-(\mathrm{OH})$ vit. D under $20 \mathrm{ng} / \mathrm{mL}$. Only two patients $(10,5 \%)$ presented with a severe deficiency and value of $25-(\mathrm{OH})$ vit. D under $10 \mathrm{ng} / \mathrm{mL}$.

CONCLUSION: We could conclude that the patients with exacerbated seborrheic dermatitis present with $25-(\mathrm{OH})$ vit. D insufficiency and deficiency. Our results allow us to suggest that vit. D may play a role in the pathogenesis of seborrheic dermatitis. Consequently, its supplementation may be used in the treatment of this pathology. To our knowledge, this is the first study of serum 25-(OH) vit. D levels in patients with seborrheic dermatitis and these results promise multiple directions for further research.
\end{abstract}

Key words: seborrheic dermatitis, vitamin D, serum 25 -hydroxyvitamin D, vitamin D insufficiency, electrochemiluminescence immunoassay

\section{INTRODUCTION}

Seborrheic dermatitis is a chronic papulosquamous disorder affecting the sebum-rich areas of the scalp, face and trunk, commonly aggravated by factors like changes in season and humidity, trauma, emotional stress, and alcohol consumption. The

Address for correspondence:

Jenya Dimitrova, $M D$

Department of Dermatology and Venerology,

Medical University of Varna

55 Marin Drinov Str., 9002 Varna, Bulgaria

E-mail: dimitrova_derm@abv.bg

Phone: +359889706042

Received: August 30, 2012

Accepted: January 15, 2013 prevalence rate of seborrheic dermatitis is 3-5\% (6) with worldwide distribution. The mildest form of seborrheic dermatitis, i.e. dandruff, is much more common and affects $15-20 \%$ of the population.

The etiology and pathogenesis of seborrheic dermatitis is not elucidated yet. While in the past Malassezia species were thought to be the main pathogenic factor, now it is considered that Malassezia levels may be normal but there is an abnormal immune response and, probably, skin-barrier dysfunction in subjects prone to this dermatitis $(13,15)$. T-helper cells, phytohemagglutinin and concavalin stimulation as well as antibody titres are reduiced in patients with seborrheic dermatitis compared with those of control subjects. 
The spontaneous remission of seborrheic dermatitis in summer and the therapeutic effect of vit. D in other papulo-squamous dermatosis such as psoriasis $(1,7,9)$ suggested us to study vit. D status of patients with seborrheic dermatitis. Even more, recent studies demonstrate that keratinocytes possess vit. D receptors which inhibit the proliferation and stimulate the differentiation of the epidermal cells $(4,5,11)$. Vit. D receptor ligands diminish the expression level of proinflamatory cytokines $(8,12,16)$ and exert therapeutic effect in many autoimmune and skin diseases (10).

The objective of the present study was to determine the serum level of 25 -hydroxyvitamin $\mathrm{D}$ $(25-(\mathrm{OH})$ vit. D) in patients with clinicaly manifested seborrheic dermatitis.

\section{MATERIAL AND METHODS}

Twenty-two seborrheic dermatitis patients, 11 females and 11males, were examined for serum 25$(\mathrm{OH})$ vit. D as the best indicator of vit. D status (17). These patients were aged between 5 and 61 years. With the exception of one male patient who was in remission in the time of testing the other patients presented with exacerbated dermatitis. Only one patient had flexural eruption. In the rest patients, scalp and face were affected. The patients were examined in the period from November to August in order to avoid the seasonal factor influencing on serum vit. D level. The latter was assessed by electrochemiluminescence immunoassay (ECLIA) method.

As nowadays there is no standard definition of optimal vit. D status, the scale used here was that one recommended by the manufacturer of the ECLIA analyzer. According to this scale, preferred level of serum $25-(\mathrm{OH})$ vit. $\mathrm{D}$ is $30-70 \mathrm{ng} / \mathrm{mL}$. The value of $21-29 \mathrm{ng} / \mathrm{mL}$ is interpreted as insufficiency and the level under $20 \mathrm{ng} / \mathrm{mL}$ as deficiency. Serum 25-(OH) vit. D levels under $10 \mathrm{ng} / \mathrm{mL}$ are evaluated as a severe deficiency $(2,3)$.

\section{RESULTS}

During the whole period of the study none of the patients showed optimal level of serum 25-(OH) vit $\mathrm{D}$. Three patients presented with suboptimal values of $25-(\mathrm{OH})$ vit. $\mathrm{D}(13,6 \%$ of the cases). These patients were male, one of them was the patient who was at remission stage during the blood examination. Interestingly, the values of those three patients were all near the lower limit of the reference interval, i. e. 30,$03 ; 34,40$ and $33,79 \mathrm{ng} / \mathrm{mL}$, respectively.

The rest 19 patients $(86,3 \%)$ showed insufficiency of 25-(OH) vit. D with values under $30 \mathrm{ng} / \mathrm{mL}$. Four patients (21\%) showed results between $21-29 \mathrm{ng} / \mathrm{mL}$ and 13 ones $(68,4 \%)$ were with pronounced deficiency - serum $25-(\mathrm{OH})$ vit. D under $20 \mathrm{ng} / \mathrm{mL}$. Only two patients $(10,5 \%)$ presented with a severe deficiency and value of $25-(\mathrm{OH})$ vit. D under $10 \mathrm{ng} / \mathrm{mL}$. Only two patients $(10,5 \%)$ presented with a severe deficiency and value of $25-(\mathrm{OH})$ vit. D under $10 \mathrm{ng} / \mathrm{mL}$. One of them was a 5-year old girl with scalp and flexural eruption. The other patient was a 18-year old female with seborrheic dermatitis of the scalp that was recalcitrant to antifungal treatment.

Patients' distribution according to age and 25$(\mathrm{OH})$ vit. D value indicated similar gender patterns. Deficiency was $31,6 \%$ and insufficiency was $10,5 \%$ in males, i.e. comparable to $36,6 \%$ and $10,5 \%$ in females, respectively (Table 1).

Table 1. Gender distribution of the patients with serum 25-hydroxyvitamin D insufficiency $(<30 \mathrm{ng} / \mathrm{mL})$

\begin{tabular}{|l|c|c|c|c|}
\hline \multirow{2}{*}{$\begin{array}{l}\text { Serum 25-(OH) } \\
\text { Vit. D values }\end{array}$} & \multicolumn{2}{|c|}{ Males } & \multicolumn{2}{c|}{ Females } \\
\cline { 2 - 5 } & $\mathrm{n}$ & $\%$ & $\mathrm{n}$ & $\%$ \\
\hline $29-21 \mathrm{ng} / \mathrm{mL}$ & 2 & 10,5 & 2 & 10,5 \\
$20-10 \mathrm{ng} / \mathrm{mL}$ & 6 & 31,6 & 7 & 36,8 \\
$<10 \mathrm{ng} / \mathrm{mL}$ & 0 & 0 & 2 & 10,5 \\
\hline \hline
\end{tabular}

When the patients with 25-(OH) vit. D deficiency (with values under $20 \mathrm{ng} / \mathrm{mL}$ ) were stratified by age it became obvious that in males, seborreic dermatitis was more common in the age group of 30-40 years. On the other hand, females aged 10-20 years showed the highest percentage (44\%) followed by those aged 20-30 and 51-60 years - 22\% each (Table 2).

\section{DISCUSSION}

In the last few years, vit. $\mathrm{D}$ is widely investigated because of the fact that except its role in calcium metabolism it possesses antiproliferative, 
Table 2. Age and gender distributions of the patients with serum 25-hydroxyvitamin D deficiency $(<20 \mathrm{ng} / \mathrm{mL})$

\begin{tabular}{|l|c|c|c|c|}
\hline \multirow{2}{*}{ Age (years) } & \multicolumn{2}{|c|}{ Males } & \multicolumn{2}{c|}{ Females } \\
\cline { 2 - 5 } & $\mathrm{n}$ & $\%$ & $\mathrm{n}$ & $\%$ \\
\hline Under 20 & 0 & 0 & 4 & 44 \\
$20-30$ & 2 & 33,3 & 2 & 22 \\
$31-40$ & 3 & 50,0 & 0 & 0 \\
$41-50$ & 1 & 16,6 & 1 & 11 \\
$51-60$ & 0 & 0 & 2 & 22 \\
\hline \hline
\end{tabular}

prodifferentiative and immunomodulatory activities $(4,8,11,14)$. Vit. D receptors are established in keratinocytes where they exert an effect on proliferation and differentiation of epidermal cells (5). Vit. D deficiency in patients with seborrheic dermatitis established by us and the well-known therapeutic effect of this vitamin in the other papulosquamous disorder, psoriasis vulgaris, allow us to believe that its supplementation may have therapeutic effect in seborrheic dermatitis, too. In addition, vit. $\mathrm{D}$ deficiency in patients with seborrheic dermatitis despite the seasonal factor necessiates additional studies of vit. D synthesis in such patients.

\section{CONCLUSION}

We could draw the conclusion thatat despite the season, the patients with exacerbated seborrheic dermatitis present with $25-(\mathrm{OH})$ vit. D insufficiency and deficiency. The absence of optimal vit. D status in such patients suggests a pathogenetic role of this vitamin. This conclusion is concordant with the well-known fact that seborrheic dermatitis patients experience a significant alleviation of the disease during summer. Consequently, its supplementation may be used in the treatment of this pathology. To our knowledge, this is the first study of serum $25-(\mathrm{OH})$ vit. D levels in patients with seborrheic dermatitis and these results promise multiple directions for further research.

\section{REFERENCES}

1. Barker, J. N., J. Berth-Jones, R. Groves, A. D. Omerod, E. Rizova, C. E. Griffiths. Calcium homeostasis remains unaffected after 12 weeks' therapy with calcitriol $3 \mathrm{microg} / \mathrm{g}$ ointment; no correlation with extent of psoriasis.- J. Dermatol. Treat.,14, 2003, No 1, 14-21.

2. Bischoff-Ferrari, H. A., E. Giovannuci,W. C. Willett, T. Dietrich, B. Dawson-Hughes. Estimation of optimal serum concentrations of 25-hydroxyvitamin D for multiple health outcomes.- Am. J. Clin. Nutr., 84, 2006, No 1, 18-28.

3. Dawson-Hughes, B., R. P. Heaney, M. F. Holick, P. Lips, P. J. Meunier, R. Vieth. Estimates of optimal vitamin D status.- Osteoporosis Int., 16, 2005, No 7, 713-716

4. Feldman, D., T. Chen, M. Hirst, K. Colston, M. Karasek, C. Cone. Demonstration of 1,25-dihydroxyvitamin D3 receptors in human skin biopsies.- J. Clin. Endocrinol. Metab., 51, 1980, No 6, 1463-1465.

5. Holland, D. B., E. J. Wood, S. G. Roberts, M. R. West, W. J. Cunliffe. Epidermal keratin levels during oral 1-alpha-hydroxyvitamin D3 treatment for psoriasis.- Skin Pharmacol., 2, 1989, No 2, 68-76.

6. Johnson, M. L. T., J. Roberts. Skin conditions and related need for medical care among persons 1-75 years, United States,1971-1974.- Vital Health Stat., 11, 1978, No 1, 1-26

7. Langer, A., W. Stapor, M. Ambroziak. Efficacy and tolerance of topical calcitriol $3 \mathrm{micrg} / \mathrm{g}$ in psoriasis treatment: a review of our experience in Poland.-

Br. J. Dermatol., 144, 2001, Suppl. 58, 11-16.

8. Manolagas, S. C., D. M. Provvedini, C. D. Tsoukas. Interactions of 1,25-dihydroxyvitamin D3 and the immune system.- Mol. Cell. Endocrinol., 43, 1985, No 2-3, 113-122.

9. Morimoto, S.,Y. Kumahara. A patient with psoriasis cured by 1 a-hydroxyvitamin D3.- Med. J. Osaka Univ., 35, 1985, No 3-4, 51-54

10. Nagpal, S., J. Lu, M. F. Boehm. Vitamin D analogs: mechanism of action and therapeutic applications.- Curr. Med. Chem., 8, 2001, No 13, 1661-1679. 
11. Nagpal, S., S. Na, R. Rathnachalam. Noncalcemic actions of vitamin $\mathrm{D}$ receptor ligands.- Endocr. Rev., 26, 2005, No 5, 662-687.

12. Pinette, K. V., Y. K. Yee, B. Y. Amegadzie, S. Nagpal. Vitamin D receptor as a drug discovery target.- Mini Rev. Med. Chem., 3, 2003, No 3, 193-204.

13. Prohic, A., E. Kasumagic-Halilovi. Identification of Malassezia species from immunocompetent and immunocompromised patients with seborrheic dermatitis.- Eur. Rev. Med. Pharmacol. Sci., 14, 2010, No 12, 1019-1023.

14. Provvedini, D. M., C. D. Tsoukas, L. J. Deftos, S. C. Manolagas. 1,25-Dihydroxyvitamin D3 receptors in human leukocytes.- Science, 221, 1983, No 4616, 1181-1183.
15. Tajima, M., T. Sugata, A. Nishikawa, R. Tsuboi. Molecular analysis of Malassezia microflora in seborrhoic dermatitis patients: comparison with other diseases and healthy subjects.- J. Invest. Dermatol.,128, 2008, No 2, 345-351.

16. Tobler, A., J. Gasso, H. Reichel, A. W. Norman, H. P. Koeffler. Granulocyte-macrophage colonystimulating factor. Sensitive and receptor-mediated regulation by 1,25-dihydroxyvitamin D3 in normal human peripheral blood lymphocytes.- $J$. Clin. Invest., 79, 1987, No 6, 1700-1705.

17. Zerwekh, J. E. Blood biomarkers of vitamin D status.- Am. J. Clin. Nutr., 87, 2008, No 4, 1087S-1091S. 